\title{
Wifehood and Silent Separatist Policy in Alan Paton’s Cry, The Beloved Country
}

\author{
Nonyelum Chibuzo Mba \\ University of Abuja, Abuja, Nigeria
}

\begin{abstract}
The paper presents abandonment, loneliness, and desolation, which defaced wifehood institution in South African polity. The disruption of family life and lack of opportunity for personal development turned women desolate and children delinquent. The problem is the non-liberal practices in South Africa in spite of the struggle of people like Alan Paton. The objective of this paper is to study the South African society as presented by Alan Paton in line with his Liberalist Theory in order to make freedom and development achievable. The main factual points are that racism still exists; most black homes are separated; most black women are not empowered; colour segregation hinder development. The methodology adopted is the interpretation discourse of Alan Paton’s Cry My Beloved Country in line with South African society. The Silent Separatist Policy, Survival and Family; Societal Plague and Women; Apartheid: Implication for Development; and Way Forward are discussed. The outcome revealed the difficulty of transforming South Africa into a complete liberal society due to racism and the need to empower women. The conclusions are: Education should be made accessible to all; Women empowered and total freedom restored.
\end{abstract}

Keywords: liberalism, separation, racism, wifehood, empowerment, freedom

\section{Introduction}

Siphokazi Koyana in "Womanism and Nation-building in Sindiwe Mogona's Autobiographies" in Agenda: Empowering Women for Gender Equity: African Feminism One (No. 50, 2001) stresses that womanism "concerns itself as much with the black political and economic powerlessness as with the black power gender struggle" (Siphokazi, 2001, p. 65). There is evidence of gender disparity across and within South African society. Poverty is the greatest among the black race and the woman is the most hit being the closest person to the children. According to Umoren (2002) in A Portrait of Womanhood in African Literary Tradition: Reflections on Elechi Amadi's works, a "woman is a concept in English Language referred to as the other sex, an adult female of a human race, a wife, a mistress, a female sex, woman collectively...” (Umoren, 2002, p. 1). A wife is therefore a married woman who ordinarily is supposed to feel the warmth and presence of her husband all the time rather than living in isolation or being humiliated by the aftermath of racism.

South Africa is a multi-racist society characterized by segregation which in turn has thrown the black race into disadvantageous position. Many blacks are subjected to extreme poverty, lack of shelter, unemployment, menial jobs with worthless wages, and so on. According to Foley (2009) in The Imagination of Freedom, 
liberalism maintains that each individual person should be allowed the maximum freedom to pursue his or her idea of the good life... Liberalism believes that each individual person is of equal moral worth, and so affirms that in society all citizens should enjoy an equality of maximum liberty. (Foley, 2009, p. 9)

The non-liberal nature of South Africa has thrown a lot of black families into separation though migration and quest for jobs in the bid to survive. Most often men take up mining jobs in different location from their families and the salary becomes so meager that they cannot afford to take care of their families. The woman who is not educationally and economically empowered is left to cater for the family. What will be her resources for meeting up with such burden? This redirects South Africans to the first and third millennium goals which are to "eradicate extreme hunger and poverty [and] promote gender equality and empower women" (UN Millennium Project, 2000, p. 1). This was the agreement reached by the World Leaders' Millennium Summit in September 2000.

The non-liberal nature of South African society has thrown a lot of families into perpetual suffering just as racism has become a torn in the flesh of South Africans. Its unending drastic effects on the family tend to multiply women's problems. According to Kolawole (1997) in Womanism and African Consciousness, the plight of the African woman is that of multiple subjugations. She says that:

patriarchy, tradition, colonialism, neo-colonialism, racism, and gender imperialism all combine to act against the African woman's self-assertion. But the plight of the alienated, divided, westernized African woman is usually taken as a norm while they try to negotiate a path through the multiple maze of oppression positively the life of the majority of African women reveals resilience and not defeat. (Kolawole, 1997, p. 25)

The effect of racism on South Africans motivated many writers to fight pen battle through which they sensitize the members of their society of the canker that is demolishing the society through a gradual process. Prominent among these writers was the liberalist writer, Alan Paton whose name is indelible in the annals of South African history.

Foley states that a key element in the achievement of Paton's (1948) novel, Cry, the Beloved Country,

lies in his moving and evocative presentation of the struggle of the two main protagonists, Stephen Kumalo and James Jarvis, a black man and white man respectively, towards mutual understanding and reconciliation in the twilight of their years. (Foley, 1948, p. 42)

The novel is divided into two parts. The first is on the difficulties experienced by people in South African society while the second reflects his exploration of possibilities of restoration.

Alan Paton proffers liberal citizenship in South Africa as justification for God's creation of human race which depict freedom for human beings irrespective of sex. As presented by Gouws (2004) in The Politics of State Structure: Citizenship and the National Machinery for Women in South Africa, "Liberal citizenship views all people as autonomous individuals who are the bearers of rights in the natural rights tradition” (Gouws, 2004, p. 28). The discussion in this paper is a two-way discussion taken side by side: racism and its aftermath and gender discourse. This paper therefore studies the South African society as presented by Alan Paton from the following angles: Societal Plague and Women; Silent Separatist Policy, Survival and Family; Apartheid: Implication for Development; and Way Forward.

\section{Societal Plague and Women}

Racism is the major societal plague in South Africa. People interpret it from different perspectives. 
For instance, while discussing African history, Ayi Kwei Armah in Two Thousand Seasons and as presented by Ikonne, Oko, and Onwudinjo (1991) in African Literature and African Historical Experiences, states that racism is "a separatist ideology as a way of safeguarding black ideology and civilization" (Ikonne, Oko, \& Onwudinjo, 1991, p. 16).

Racism promotes inequality, marginalization, exploitation, and crime due to the condition of the less privileged in the society. It also promotes gender inequality as in most cases it tends to be patriarchal in nature. Such gender disparity breeds humiliation and dehumanization. The condition of women in comparison to men ascertains the gender imbalance in South Africa. For instance, during Kumalo's trip to Johannesburg, he entered into the carriage for non-Europeans, already full of the humbler people of his race, some with strange assortments of European garments, some with blankets over the semi-nudity of their primitive dress, though these were all women. Men traveled no longer in primitive dress (Paton, 1948, pp. 14-15).

The above description is a clear indication of the existence of racism, under empowerment of women and marginalization. Why should women be qualified with the adjectives: "semi-nudity and primitive" if not in comparison with their male folk who seem to be better placed? Many writers who know the need of human rights condemn such attitudes. George-Genyi (2005), for instance in "Endangering Human Rights: The Case of Domestic Violence in Nigeria" in Perspectives on Violence Against Women in Nigeria, posits that "the human person is born free without undue encumbrances and constraints against one's abilities to enjoy the circumstances in one's life" (George-Genyi, 2005, p. 93).

Racism generates a lot of suffering and poverty among the blacks. They suffer untold hardship right from the early stage of their lives. Children suffer and engage in several crimes to survive. They attack and rob the whites in retaliation of their suffering. The blacks are hardened and are shock absorbers in themselves because they have passed through a lot of things in their lives. Paton (1948) confirms that life to most blacks means survival of the fitness and that the end justifies the means. He says that:

sometimes two white men and women sit in their cars in the dark under the trees on the Pretoria road; and some of our young men sometimes rob and assault them, sometimes even the women. It is true that they are often bad women, but that is the one crime we dare not speak of. (Paton, 1948, p. 42)

The economic situation of South Africa as portrayed by Alan Paton ushered in a high level of crimes in the society. It is believed that blacks, especially youths indulge in crimes to keep body and soul together. This is evident in the discussion of the Priests.

So they all talked of the sickness of the land, of the broken tribe and the broken house, of young men and young girls that went away and forgot their customs, and lived lives. They talked loose and idle of young criminal children, and older and more dangerous criminals, of how white Johannesburg was afraid of black crime... (Paton, 1948, p. 2)

Crime however is not limited to the blacks alone who use it as escapist root. It very much extends to the whites as in the case of the white woman who was scarcely with a rag.

The rate of crime became so alarming that people were afraid of their lives. Expressing such fear, one of the priests (Msimangu) explained that "it was not long ago that one of our own African girls; they took her bag, her money, and would have raped her too but that people came running out of their houses” (Paton, 1948, p. 22). There is insecurity in the society especially for the girl-child. Paton x-rays the predicament of the blacks and wonders the type of future that awaits blacks. Umoren (2002) said that "the black woman is loud; emasculating, obstinate and generally immoral while the white woman is everything virtuous: blue-eye, pedestal queens" 
(Umoren, 2002, p. 5). This is one of the discriminatory tendencies in a racist society. Everything good is attributed to white colour just as the devil is always painted black.

The condition of the black woman in a racist country is pathetic and complex. At times she is sexually assaulted. Those who are opportune to work are mentally and physically conditioned to work with meager wages. The less privileged and uneducated ones most often do debasing things for survival. Social and psychological violence is meted on them. The dehumanizing image of the woman, whether black or white, places her in the kitchen, a highly disadvantaged position. The general impression about women is that they are mothers, wives and also prostitutes as they most often use what they have (sex) to survive as Alan Paton painted in the life of Gertrude, Stephen Kumalo's sister. This negative attribution of prostitution to women is common in Africa. Every society perceives women from particular angle as wives, mothers, traders, prostitutes, political workers, and so on. Women most often share similar experiences. Mrs. Lithebe was the woman that housed Gertrude and her son. They worked together and shared their experiences in life; "But the good Mrs. Lithebe was there, and she and Gertrude talked long and simply about things dear to the heart of women, and they worked and sang together in the performance of the daily tasks” (Paton, 1948, p. 5).

Considering the effect of racism on both family and children, most children suffer untold hardship, move anyhow, live apart from their parents and engage in all sorts of crimes. This is evident in the life of the girl whom Absalom Kumalo made pregnant. The girl has nobody cater for her. But the question remains, why should somebody like Absalom Kumalo claim that he has nobody too? Absalom who was living in the reformatory before has wondered away leaving the girl alone. At Pimville, the poor girl has no idea of his where about. But Absalom who was the head-boy in the reformatory behaved well. So many children grew up in Johannesburg without home, school, custom, and the comforts of life.

Laws of Segregation are imminent in South Africa and generate a lot of discrimination and discrepancies. The whites segregate against the blacks and as such, areas and properties are owned according to race. For instance, trams differ and generate problems in Johannesburg and according to Paton (1948), "they run trams from the centre of the city, and part is for Europeans and part for us. But we are often thrown off the trams by young hooligans. And our hooligans are ready for trouble too” (Paton, 1948, p. 27). In the same vein, due to joint ownership of the Bantu Press, the newspaper release of information is restricted. Not every truth is told the public. This can also be compared to neocolonial African societies like Nigeria where the government owned press select information suitable for public hearing.

Every society has black sheep and South Africa is not an exception. This Alan Paton portrays in the character of John Kumalo and his fellow politician friends who baptized the Bantu Press as "Bantu Repress" (Paton, 1948, p. 27). The "...shabbiness and dirtiness, and the closeness of the houses, and the filth in the streets" (Paton, 1948, p. 7) of Claremont are symbolic of the rottenness of the society. Most children roam the streets uncared for and liquor is the main business of women. The level of decadence in the society is such that taunt the lives of some Christians. For instance, Msimangu confirms that:

there is a woman of our church there, and a good woman who tries with her husband to bring up good children. But it is hard. Their eldest daughter whom I prepared for confirmation has run away, and lives in Pimville, with a young loafer of the streets. (Paton, 1948, p. 28)

Violence against women transcends race discrimination as a white man meted it out on a fellow white woman, defiled her and dumped her in a winter's night and she came knocking on Msimangu's friend's door 
along Potchefstroom road. Johannesburg is a place of all activities, where all manner of things, whether good or bad, are possible.

All roads lead to Johannesburg. If you are white or if you are black they lead to Johannesburg. If the crops fail, there is work in Johannesburg. If farm is too small to be divided further, some must go to Johannesburg. If there is a child to be born that must be delivered in secret, it can be delivered in Johannesburg. (Paton, 1948, p. 48)

Mostly blacks rent houses in Alexandra or Sophia town or Orlando. They are usually congested in a room, at times about 10 people in one room.

Murder is very common in the society as can be seen in the killing of a well-known city Engineer who was shot in his house in Parkwold by assailants who were thought to be natives. The white man laments,

This is a terrible loss for South Africa, said the white priest. For this Arthur Jarvis was a courageous young man, and a great fighter for justice. And it is a terrible loss for the church too. He was one of the finest of all our young laymen. Jarvis... He was the President of the African Boys’ Club, here in Claremont, in Gladiolus street. (Paton, 1948, p. 65)

He was the only child of Mr. James Jarvis of the High Place farm, Carisbrooke, Natal. His death was a tragedy and a great loss to the citizens because the dead man was well known for his interest in social problems and had made several efforts for the welfare of the non-European sections of the community.

Alan Paton states in a concise manner, the situational context of the blacks and criminology as well as the possible solution to combat crime. This is embedded in the resolution read out by Mr. McLaren,

I say we shall always have native crime to fear until the native people of this country have worthy purposes to inspire them and worthy goals to work for. For it is only because they see neither purpose nor goal that they turn to drink and crime and prostitution. (Paton, 1948, p. 8)

\section{Silent Separatist Policy, Survival and the Family}

The silent separatist policy in South Africa, economic situation, and quest for survival have scattered the members of Stephen kumalo's family all over Johannesburg. The disintegration of the family is in the bid to survive. For instance,

his brother, John Kumalo, who was a carpenter, owns a business in Sophia town, Johannesburg. His sister, Gertrude, went to Johannesburg in search of her husband who works in the mines. His only son, Absalom, went to look for his aunt, Gertrude. None of these people returned. (Paton, 1948, p. 9)

Poverty has eaten deep into the fabrics of the black community. The girl-child, the mother of future generations, is not empowered for survival due to racism. She does menial jobs like being a sales girl, a messenger, etc. This is the picture Alan Paton paints in the girl who delivered letter to Kumalo. Poverty is very evident in the fear that moderated the girl's movement in Kumalo's house in which she "went delicately to the door, and shut it behind her gently, letting the handle turn slowly like one who fears to let it turn fast" (Paton, 1948, p. 10). Under empowerment is a gender case in South Africa engendered by racism.

Men and women, boys and girls go about in the quest to survive in their own way. The type of life they live does not matter much to them so far it keeps body and soul together. This disorganizes parents' plan for their children as in the case of Kumalo who wants his son Absalom to "go to St. Chad's to learn that knowledge without which no black man can live” (Paton, 1948, p. 11). Such disintegration of the family has serious negative impact on the members. No one cares for each other in the process. This is the fact behind Kumalo's complaint "my own son, my own sister, my own brother. They go away and they do not write any more. 
Perhaps it does not seem to them that we suffer. Perhaps they do not care for it” (Paton, 1948, p. 1).

Alan Paton presents the silent separatist policy in this way,

the compound system, that brings men to the towns without their wives and children, and breaks up the tribe and the house and the man, and they ask for the establishment of villages for the labourers in mines and industry. (Paton, 1948, p. 70)

Such separation of man and his family results in chaos in the home especially as in most cases, the women are not empowered. Things then fall apart in the homes when the men who are the breadwinners are taken away. Most children go away wandering about in the quest to survive.

Women bear the brunt of every situation in the home. They propel wheels of action and are motivators of their husband's actions. Their husbands handle them as subordinates as can be seen in Stephen Kumalo's wife- the opening and reading of the letter from Johannesburg. The failure of children is attributed to women hence the feeling of Kumalo's wife who was "hurt by his accusation” (Paton, 1948, p. 11). But in Kumalo's case, he is not willing to hurt his wife. This is evident in his declaration when his wife told him that he is hurting him, "that I may not do" (Paton, 1948, p. 12).

In like manner, Mrs. Kumalo plans ahead for her husband's future and maintenance of his career. She said to the husband, "and that other money, though we saved it for St. Chad's, I had meant it for your new black clothes, and a new black hat, and new white collars" (Paton, 1948, p. 2). There is mutual understanding between the husband and the wife thus making the problems lighter. Religion played vital role in uniting husbands and wives who are committed Christians. This is clearly illustrated in the kind of relationship that exists between Stephen Kumalo and his wife. Husband's love and care of the wife in spite of his meager resources and very tight economy is depicted in the actions, plans, utterances of Reverend Stephen Kumalo to the wife. "I have been saving that for your stove" (Paton, 1948, p. 2). In like manner, Mrs. Kumalo plans ahead for her husband. She said to him, "and that other money, though we saved it for St. Chad's, I had meant it for your new black clothes, and a new black hat, and new white collars” (Paton, 1948, p. 12). Alan Paton therefore proffers mutual understanding and unity as solutions to racism which has eaten deep into the fabrics of South African society. Good Christian homes however are not limited to race discrimination.

Alan Paton portrayed the epitome of the black woman suffering in most of his female characters. This is evident in Mrs. Kumalo. The two basic characteristics of a suffering black woman are silence and patience. Mrs. Kumalo "was silent, with the patient suffering of black women with the suffering of oxen, with the suffering of any that are mute" (Paton, 1948, p. 12).

The silent separatist policy causes disintegration of families, untold hardship and death. The same situation affected another family, the Mpanza family of Ndotsheni. After 12 years of separation from one another, Mrs. Mpanza saw the tragic death of her son, Michael on the street of Johannesburg which is characterized by busy movement of automobiles

...the wife of Mpanza of Ndotsheni, who had gone there when Mpanza was dying, saw her son Michael killed in the street. Twelve years and moved by excitement, he stepped out into danger, but she was hesitant and stayed at the kerb. And under her eyes the great lorry crushed the life out of her son. (Paton, 1948, p. 4)

People do menial jobs to survive. Sibeko's daughter works for the white man Smith in Ixopo. She was taken away to springs and could not communicate with the parents 
...Sibeko's daughter worked here for the white man smith in Ixopo. And when the daughter of Smith married, she went to Johannesburg, and Sibeko's daughter went with them to work... But Sibeko has heard no word of his daughter these ten, twelve months... (Paton, 1948, p. 14)

The silent separation policy of the racist South Africa is embedded. Migration of people to other parts of South Africa also reflects in the lives of the Zulus who migrated to areas that speak Afrikaans. "The mines, they cry, the mines; for many of them are going to work in the mines” (Paton, 1948, p. 16).

The whites take husbands and even some women out of their families without considering its effects on people. When communication fails, life becomes a threat and insecurity overcomes human. That same fear of the unknown took over kumalo while discussing with Msimangu. Kumalo's explanation to him is

she came to look for her husband who was recruited for the mines. But when his time was up, he did not return, nor did he write at all. She did not know if he were dead perhaps. So she took her small child and went to for him. (Paton, 1948, pp. 22-23)

The negative effect of the separation of home and very poor economic status is unquantifiable. The under empowerment of women and even men threw them into mean ways of survival as can be seen in the case of Kumalo's sister who became husbandless, very sick and at the same time, has not found her husband. Kumalo did not just come in search of his sister, but also his only son, Absalom, who earlier came to look for his aunt.

Johannesburg is symbolic of a playground which accommodates different species of players aiming at a particular goal of achieving success. Success differs in the eyes of agitators but has to do with survival which is a necessity to life and which must be played out in different ways to be achieved. In this case the environment plays an important role on the players and that environmental influence is the propelling wheel of players' actions but the major determinants of such influence are economically and politically based. Hence, according to Msimangu, John Kumalo is of the opinion that "what God has not done for South Africa, man must do..." (Paton, 1948, p. 25). In him, Alan Paton paints the picture of politicians in Africa generally whose basic characteristics are empty and impossible promises and self-aggrandizement. In summary, everything is geared towards achieving their selfish ends.

Among the reasons why people in Johannesburg forget their people are financial hardship, congestion in rooms and lack of accommodation. For instance, Mrs. Seme is number six thousand in the list of those looking for house. A lot of problems emanate from congested houses. People quarrel a lot over items in the house and the way they look at people, "we have quarreled about the stove, we have quarreled about the children, and I do not like the way the man looks at me” (Paton, 1948, p. 50). There is neither privacy nor safety in such congested environment. It is not even healthy for family and children's upbringing. Such environment is a microcosm of different characters, both good and bad, crimes and situational complexity.

Further on the quest for survival, most women don't actually like the kind of life they live only that is the only way out. Most of the women are careless about their children and yet claim them as the reason for the life they live. Stephen Kumalo's summary of his sister's activities is, "you have shamed us... A liquor seller, a prostitute, with a child and you do not know where it is. Your brother is a priest...” (Paton, 1948, p. 29). Even the prostitution is not very lucrative. Gertrude’s statement is "I do not like Johannesburg...” (Paton, 1948, p. 29). She confirms her status, "I am a bad woman, my brother, I am no woman to go back” (Paton, 1948, p. 30). Gertrude's repentance and remorsefulness is revealed through an outburst, "into a torrent of prayer, of self-denunciation and urgent petition” (Paton, 1948, p. 30). This is an indication that conditions can be mended 
if properly taken care of. Ironically, Gertrude who is described as the richest woman has just a few belongings like a table, chairs, and a bed. Even when her child appeared, he wore dirty cloth and had running nose.

John Kumalo has a broken home. His wife, Esther left him 10 years ago and he is already living with another woman who he did not marry in Christian way. Separatism, exploitation, suffering characterize the lives of the blacks in South Africa. The role of the blacks most often, is to work while the whites enjoy the fruit of their labour. Racism breeds inhumanity and the unfeeling nature of the whites and untold hardship suffered by the blacks. Any discovery of gold means separation of more families. The whites employ of blacks to dig at a very cheap rate, making them resident for access.

They go mad when new gold is found. They bring more of us to live in the compounds, to dig under the ground for three shillings a day... Every factory, every theatre, every beautiful house; they are all built by us. (Paton, 1948, p. 35)

However, John Kumalo prefers Johannesburg than back home due to recognition which he conspicuously lacks at home.

Polygamy causes John Kumalo's son to leave the house and settle at Alexandra working for a factory. Quest for survival also separates the black parents from their children. Absalom and his cousin, John Kumalo's son engages in factory work in Alexandra. Stephen Kumalo's search for his son, Absalom, took him to different places without much success. He even went to the reformatory where he discovered that a girl was pregnant for him. On locating her, he realized that Absalom has abandoned her in the quest for survival, though he got the information that "he seemed fond of her, and anxious about the child that would be born... the girl too seemed fond of him..." (Paton, 1948, p. 60). The girl in question has nobody as earlier stated. But marriage is organized between them.

Stephen Kumalo who came all the way from Ndotsheni to Johannesburg never envisaged such disaster as his family has turned to be. The trend of events created fear in him but from Father Vincent's perspective, "sorrow is better than fear... fear is a journey, a terrible journey, but sorrow is at least an arriving" (Paton, 1948, p. 96). The turnout of events in Kumalo's life tallies with the saying that man proposes but God disposes hence man's unpredictability of God's way in doing things. Kumalo eventually failed to re-unite his family. The girl Absalom got pregnant was a victim of circumstance. She had a mother who is a drunk and her father abandoned her with a daughter and two sons. She said to Kumalo, "my father left my mother, Umfundisi. And my second father I could not understand” (Paton, 1948, p. 100). Children are always the victims of broken homes.

Marriage, especially among the blacks, is characterized with poverty, separation in the quest to survive, unhappiness, desolation and lacks the necessary ingredients of life with love and care being absent too. Absalom's young wife feels desolate, hopeless and deserted in her situation. She tells her father-in-law, "he went on Saturday to spring... and he has not yet returned” (Paton, 1948, p. 62). Paton describes her condition as "she said it tonelessly, hopelessly. And who is used to waiting, to desertion... " (Paton, 1948, p. 62). Wife in Paton's fictional world means suffering, endurance, patience, desolate, hopeless, neglect, deserted, and struggle. All these are engendered by the societal economic situation which is characterized by racism, poverty, hunger, suffering, migration in quest for job and separation of husband and wife. For instance, most of the gold miners don't go to the mines with their families.

\section{Apartheid: Implication for Development}

The apartheid policy can be a replica of Onyemaechi Udumukwu's view in The Novel and Change in 
Africa about colonialism which he believes has no "common ground, a ground of equality between the west and Africa. On contrary, it was predicated on the basis of differences. It perceived the colonized as the other" (Paton, 1948, p. 24). This is in line with the position of the blacks in South Africa whom the white South Africans regard as inferior, each group with its own cultural pattern. Culture is interwoven within civil society which Udumukwu defines as "a colligation of voluntary or non-coercive affiliations such as educational institutions, families, unions and culture” (Paton, 1948, p. 22). Another side effect of apartheid in South Africa as presented by Paton is the cutting of South Africa "into separate areas, where white can live without black, and black without white, where black can farm their own land and mine their own minerals and administer their own laws" (Paton, 1948, p. 70).

The church is an agent of socialization and Biblically, creation confirms freedom and equality of individuals. In the spiritual realm, there is no recognition of race, no discrimination except in righteous disposition. But physically, apartheid as confirmed by Paton exists in the church. There should therefore be interaction between elements of civil society and the political society. The essence of the discourse on silent separatist policy and the condition of the blacks therefore is in line with Bhabha's (1994) aim of colonial discourse in The Location of Culture which he says is "to construe the colonized as a population of degenerate types on the basis of racial origin, in order to justify conquest and to establish systems of administration and instruction" (Bhabha, 1994, p. 101).

Foley summarizes the situation in Johannesburg through Kumalo's experience.

In Johannesburg, then, Kumalo is brought face to face with the poverty and squalor of the townships; he is appalled by the descent into crime, wrong-doing and corruption of so many people, including his own relatives; he is confronted everywhere in the city by the fact of white oppression, racial inequality and injustice; and he is horrified by the infrastructural inadequacies of African life in the city as a whole. (Foley, 2009, p. 47)

Looking at the above specified problems, what is the guarantee of achieving the millennium goals in South African society in the next decade? These goals as specified in UN Millennium Project are

eradicate extreme hunger and poverty....achieve universal primary education... promote gender equality and empower women... reduce child mortality... improve maternal health... combat HIV/AIDS, malaria and other diseases... ensure environmental sustainability... develop a global partnership for development. (UN Millennium Project, 2000, p. 1)

For the above to be feasible in South Africa, there has to be total eradication of apartheid, and gender/race empowerment and mainstreaming must be achieved. No wonder Alan Paton is emphatic about the implementation of liberal policies. .

\section{Conclusion}

Crime reduces when life is worth living to people, when life is purposeful. If education is made accessible to children especially black children, there should be remarkable decrease in juvenile delinquency among native children. Because total freedom, equal opportunities, and proper implementation of human rights are not assured, Paton raises an alarm that ends in a note of warning to the unborn generation. Wifehood should be reversed from its circumstantial interpretation as subjugation, slavery, abandonment, misery, prostitution and so on to empowered and national builders. Same should be the status of children. Then the entire South African society should be radiating with total freedom and equal opportunity to all citizens irrespective of colour.

The summary of the situation in South African society lies in Achebe's (1958) words in the introduction of 
Things Fall Apart. He says, "things fall apart: the centre cannot hold; more anarchy is loosed upon the world" (Achebe, 1958, p. v). The aftermath of racism is engulfing the blacks in South Africa. Proper amendment of the situation seems unachievable in Paton's fictional society. Achebe's conclusion is based on the outcome of colonization of Nigeria by the whites. Msimangu too, as presented by Alan Paton, draws his own inferences from the outcome of apartheid in South Africa and from Christian perspectives. He says to Stephen Kumalo,

the tragedy is not that things are broken. The tragedy is that they are not mended again. The white man has broken the tribe. And it is my belief... that it cannot be mended again. But the house that is broken, and the man that falls apart when the house is broken, these are the tragic things. This is why children break the law, and old white people are robbed and beaten. (Paton, 1948, p. 25)

His conclusion is based on his observation of South African society generally and the lives of the people in Johannesburg where he resides.

\section{Way Forward}

(1) Adoption of liberalist views towards life among people of the world.

(2) Articulation, adoption and practice of Christian doctrine among Christians in spite of race one belongs to.

(3) People should develop sense of brotherhood and be each other's keeper. Encourage the younger generation to see themselves as one in spite of their colour so as to sustain the interaction existing among the blacks and the whites in contemporary South African society.

(4) Freedom for all citizens irrespective of colour.

(5) Gender Empowerment especially for women and gender / race mainstreaming.

(6) Prohibition of liquor and enforcement of the law.

(7) Forgiveness. Give the desolate a sense of belonging, help through empowering them.

(8) Women should learn to live independent of their husbands. Be self-actualized, where education is not affordable, do a clean business and if the capital is not readily there, engage in paid work no matter how little the salary is.

\section{References}

Achebe, C. (1958). Things fall apart. USA: Heinemann Educational Books Inc..

Bhabha, H. (1994). The location of culture. London: Routledge.

Foley, A. (2009). The imagination of freedom: Critical texts and times in contemporary liberalism. Johannesburg: Wits University Press.

George-Genyi, M. (2005). Endangering human rights: The case of domestic violence in Nigeria. In C. Angya (Ed.), Perspectives on violence against women in Nigeria. Markudi: ABOKI Publishers.

Gouws, A. (2004). The Politics of State Structure: Citizenship and the National Machinery for Women in South Africa. In A. Mama (Ed.), Feminist Africa: National politics. Rondebosch: African Gender Institute, All Africa House, University of Cape Town.

Ikonne, C., Oko, E., \& Onwudinjo, P. (1991). African literature and African historical experiences. Ibadan: Heinemann Educational Books Nigeria PLC.

Kolawole, M. (1997). Womanism and African consciousness. New Jersey: African World Press.

Koyana, S. (2001) “Womanism and Nation-Building in Sindiwe Mogana's Autobiographies in Lou Haysom. In Agenda: Empowering women for gender equity: African feminism one. No. 50. Durban: Feminist Media Section 21 Company.

Millennium Project. (2000). Retrieved from http://www.unmillenniumproject.org/goals/index.htm Web

Paton, A. (1948). Cry, the beloved country: A story of comfort in desolation. England: Penguin Books Ltd.. 
Udummukwu, O. (2006). The novel and change in Africa. Port-Harcourt: University of Port-Harcourt Press.

Umoren, T. (2002). Portrait of womanhood in African literary tradition; reflections on Elechi Amadi's works. Calabar: Clear Lines Publications \& CATS Publishers. 